\title{
FAKTOR PEMBENTUK RESILIENSI REPORTER GENERASI MILENIAL DI PT JAWA POS KORAN SURABAYA
}

\author{
Muhammad Sholahuddin \\ Program Studi Magister Pengembangan Sumber Daya Manusia \\ Sekolah Pascasarjana Universitas Airlangga Surabaya \\ Email: kanghoedjp@gmail.com
}

\begin{abstract}
Abstrak
Penelitian ini bertujuan untuk mendeskripsikan tentang faktor pembentuk resiliensi reproter atau wartawan generasi milenial di PT Jawa Pos Koran, Surabaya. Resiliensi merupakan kemampuan seseorang untuk menyesuaikan diri dan tetap survive meskipun menghadapi situasi yang sulit. Penelitian ini menggunakan jenis penelitian deskriptif kualitatif, dan mengambil lokasi di PT Jawa Pos Koran Surabaya. Informan atau partisipan dalam penelitian ini adalah 5 (lima) orang yang terdiri dari 4 (empat) reporter laki-laki dan 1 (satu) reporter dari generasi milenial yang bekerja di Koran Jawa Pos Surabaya. Metode pengumpulan data yang digunakan dengan menggunakan metode wawancara, observasi, dan dokumentasi. Teknik yang digunakan dalam melakukan analisis data adalah reduksi data, penyajian data, dan pengambilan kesimpulan. Hasil penelitian menunjukkan bahwa faktor pembentuk resiliensi reporter generasi milenial di PT Koran Jawa Pos di Surabaya mempunyai faktor yang berbeda-beda pada kemampuan resiliensinya. Faktor internal yang mempengaruhi resiliensi reporter generasi milineal di PT Jawa Koran dominan terlihat pada faktor regulasi emosi, pengendalian impuls, empati, efikasi diri, dan reaching out. Adapun faktor eksternal terlihat pada faktor dukungan keluarga dan pergaulan yang mendominasi pada reporter generasi milenial di PT Jawa Pos Koran Surabaya dalam mewujudkan kemampuan resiliensinya.
\end{abstract}

Kata Kunci: Resiliensi, Reporter, Generasi Milenial

\begin{abstract}
This study aims to describe the factors of forming the resilience of millennial generation reporters in PT Jawa Pos Koran, Surabaya. Resilience is person's ability to adapt and survive even when a person face of difficult situations. This research uses a qualitative descriptive research type, and takes location in PT Jawa Pos Koran Surabaya. Informants or participants in this study were 5 (five) person consisting of 4 (four) male reporters and 1 (one) female reporters from the millennial generation in the PT Jawa Pos Koran Surabaya. Data collection methods used by using the method of interviews, observation, and documentation. Techniques used in conducting the data is data reduction, data presentation, and conclusion. The results showed that the factors forming the resilience of millennial generation reporters at PT Koran Jawa Pos Surabaya experienced by each subject. Internal factors affecting the resilience of millennial generation reporters in PT Jawa Koran are dominantly seen in emotion regulation factors, impulse control, empathy, selfefficacy, and reaching out. Whle external factors are in family support and social that dominate the millennial generation reporters in PT Jawa Pos Koran Surabaya in realizing their abilty resilience.
\end{abstract}

Keywords: Resilience, Reporter, Millennial Generation 


\section{PENDAHULUAN}

Reporter adalah orang yang mencari, mengumpulkan, mengolah dan menuliskan informasi menjadi berita, untuk kemudian disiarkan melalui media massa. Baik itu media cetak ataupun media eletktronik (Djuroto, 2004). Dalam menjalankan tugasnya, para reporter mengumpulkan informasi dengan berbagai cara termasuk tips, siaran pers, investigasi, dan peristiwa saksi. Mereka menjalankan itu melalui wawancara, catatan publik, dan sumbersumber lain.

Kini, monopoli wartawan yang bekerja dalam sebuah kantor berita dan media massa konvensional seperti itu telah berakhir. Garis waktu seperti dikenal dalam media konvensional, yaitu harian, mingguan, dwi mingguan, atau bulanan, saat ini sudah tidak lagi relevan. Suatu peristiwa tidak lagi mengharuskan kehadiran reporter sebagai utusan dari korporasi media untuk melakukan peliputan dan kemudian menyampaikan ke publik. Dunia telah sampai di zaman yang memungkinkan siapa saja untuk mengumpulkan, mengolah, menganalisa, dan menyampaikan sendiri informasi serta menyebarluaskannya. Aktifitas yang pada masa lalu hanya dimonopoli oleh wartawan demikian itu kini bisa dilakukan siapa saja, kapan saja, dan di mana saja. Inilah bagian dari era Revolusi Industri 4.0.

Klaus Schwab dalam bukunya, The Fourth Industrial Revolution, menyebutkan, revolusi Industri 4.0 telah mengubah hidup dan kerja manusia. Zaman revolusi keempat ditandai dengan sistem cyber-physical. Industri telah menyentuh dunia virtual, berbentuk konektivitas manusia, mesin dan data, semua sudah ada di mana-mana. Istilah tersebut dikenal dengan nama internet of things (IoT). Era di mana orang mengkonsumsi sekaligus memproduksi informasi dan hiburan. (Cardoso, 2006).

Semakin banyaknya alternatif dalam memperoleh informasi tersebut pada gilirannya akan membawa dampak pada semakin ketatnya persaingan dalam perusahaan-perusahaan media massa. Perusahaan yang mampu memenuhi kebutuhan masyarakat akan mendapatkan kepercayaan, sedangkan yang gagal untuk memenuhinya akan ditinggalkan. Oleh karena itu, perusahaan media massa harus adaptif dengan terus melakukan penyesuaian-penyesuaian. Termasuk mempersiapkan dan meningkatkan kompetensi sumber daya manusia (SDM) yang dimiliki. Adaptasi dengan perubahan menjadi kunci utama agar perusahaan media berita dapat bertahan dan profitable. (Meyer, 2009)

Pada lini industri media massa, wartawan adalah urat nadinya. Adopsi atas perubahan teknologi informasi tersebut, juga menuntut perusahaan media untuk memiliki wartawan yang multiplatform, multiskilling, dan multitasking. Tuntutan yang makin besar itu bermuara pada kepentingan pemilik usaha untuk mengejar keuntungan yang sebesar-besarnya. Dalam kondisi ini, terjadi komodifikasi wartawan, yang menempatkan mereka sebagai alat produksi guna memaksimalkan keuntungan. Di antaranya, penambahan jam kerja, kejar target, tugas ganda, upah rendah, kewajiban pemasaran dan adaptasi (Pratopo dan Kusajibrata, 2018).

Kondisi demikian itu berpengaruh terhadap gangguan kesehatan wartawan seperti terjadinya serangan jantung prematur dan tekanan darah tinggi sebagaimana hasil penelitian Dart Centre For Journalism \& Trauma (2006). Selain secara fisik, wartawan juga rentan mengalami gangguan 
psikologis. Pekerjaan yang memiliki beban kerja yang tinggi serta tekanan waktu (deadline) yang tinggi membuat individu merasa tertekan dan akan menimbulkan stres. Dalam survei CarrerCast seperti dimuat dalam situs Forbes, reporter newspaper masuk The Most Stressful Jobs of 2017 di urutan keenam, di bawah event coordinator, police, airline pilot, firefighter, dan military personnel.

Seringnya menyaksikan kejadiankejadian traumatis seperti kerusuhan, korban pembunuhan atau bencana alam juga dapat menimbulkan pengaruh psikologis. Profesi reporter juga memiliki risiko ancaman keselamatan yang tinggi. Sudah banyak kejadian yang menimpa reporter seperti saat meliput berita di daerah konflik. Selain itu, permasalahan rendahnya tingkat kesejahteraan juga dapat menambah beban kerja reporter (Molkan, 2007).

Peristiwa yang membuat stres pada waktu yang berbeda dalam hidup seorang reporter memiliki arti yang berbeda-beda. Baik itu sumber stres (stressor) yang dihadapi, seberapa berat, dan berapa lama hal tersebut berpengaruh. Seberapa baik individu dapat mengatasi dampak dari stres juga bergantung pada faktor sumber daya yang dimiliki. Stres dapat menimbulkan perasaan tidak berdaya, kehilangan harapan untuk melanjutkan hidup dan depresi. Dampak-dampak tersebut merupakan tahap menuju perilaku maladaptif. Perilaku maladaptif memberikan dampak buruk bagi perkembangan dan kelangsungan hidup manusia (Lazarus dan Folkman, 1984). Dibutuhkan suatu kemampuan untuk dapat gigih bertahan dan beradaptasi kembali ketika menghadapi tekanan, kegagalan atau kesulitan-kesulitan tersebut, kemampuan ini disebut sebagai resiliensi. Konsep resiliensi digunakan untuk membedakan reaksi seseorang ketika menghadapi kesulitan dengan orang lain yang mengalami hal yang serupa, namun tidak mengalami kesusahan sama sekali (Dyer dan McGuinness, 1996).

Resiliensi yang dimiliki oleh seorang individu, mempengaruhi kinerja individu tersebut di lingkungannya, memiliki efek terhadap kesehatan individu tersebut secara fisik maupun mental, serta menentukan keberhasilan individu tersebut dalam berhubungan dan berinteraksi dengan lingkungannya. Resiliensi terdiri atas tujuh aspek, yakni regulation, impulse control, optimism, causal analysis, self efficacy, empathy dan reaching out. Kemampuan tersebut dapat dipelajari dan dapat ditingkatkan melalui pembelajaran yang disengaja dan dibiasakan (Reivich dan Shatte, 2002).

PT Jawa Pos Koran adalah perusahaan media cetak yang sudah berdiri sejak 1 Juli 1949. Perubahan yang kini telah sampai pada era Revolusi Industri 4.0 juga mengharuskan perusahaan tersebut untuk melakukan adaptasi-adaptasi. Termasuk para reporternya sebagai SDM utama yang dimiliki. Dengan demikian, tetap mampu bertahan di tengah semakin ketatnya persaingan.

Dari data penelitian pendahuluan yang telah dilakukan penulis, saat ini reporter Jawa Pos adalah para generasi Y atau milenial, yaitu mereka yang lahir pada tahun 1981-1999 (Lancester dan Stillman, 2002). Generasi ini umumnya dicirikan dengan keinginan untuk bebas beraktivitas, menyukai fleksibilitas, menyukai keterbukaan, dan mampu melihat permasalahan dalam perspektif yang berbeda. Akan tetapi, generasi ini juga memiliki komitmen yang rendah terhadap organisasi sehingga membuat mereka sering memutuskan untuk berpindah-pindah tempat bekerja. Selain itu, para generasi milenial sebagai generasi yang produktif dan bangga 
apabila dapat bekerja lebih cerdas, namun bukan kerja lebih keras. (Hannus, 2016).

Pada saat tuntutan, beban kerja, dan ancaman risiko semakin bertambah berat, reporter dari generasi milenial memiliki beberapa kelemahan karakter yang berpotensi tidak sejalan tujuan perusahaan tersebut. Ada gap antara keinginan atau harapan perusahaan dengan kondisi SDM yang senyatanya. Berangkat dari fenomena tersebut, penulis menduga hal itulah yang membuat reporter di Jawa Pos dalam beberapa tahun terakhir banyak yang memilih keluar (turnover). Namun demikian, ada pula sebagian yang mampu bertahan karena kemungkinan memiliki faktor-faktor yang ada dalam konsep resiliensi.

Penelitian tentang resiliensi sudah banyak dilakukan sebelumnya. Namun, dari penelusuran kepustakaan yang dilakukan penulis, penelitian tentang resiliensi lebih banyak dalam bidang klinis, bidang sosial dan latar belakang pendidikan. Sedangkan penelitian tentang resiliensi yang terkait SDM atau pekerja industri dan organisasi sejauh ini masih terbilang jarang. Termasuk yang secara spesifik meneliti tentang resiliensi pada profesi reporter generasi milineal yang dari hasil penelitian beberapa lembaga dicirikan sebagai angkatan kerja dengan kerentanan stres lebih tinggi. Atas dasar itu peneliti tertarik untuk menelaah mengenai faktor yang menyebabkan reporter generasi milenial yang tetap mampu bertahan di tengah tekanan dan kesulitan tersebut. Penelitian ini difokuskan pada "Faktor pembentuk resiliensi generasi milenial di PT Jawa Pos Surabaya".

\section{METODE PENELITIAN}

Jenis penelitian yang digunakan adalah penelitian kualitatif deskriptif. Partisipan atau subjek dalam riset ini ditentukan secara purposif dengan kriteria inklusif, yaitu (1). Reporter generasi milenial atau yang lahir pada tahun 1981 hingga 2000 yang bekerja di PT Jawa Pos Koran di Surabaya, (2). Berdasarkan hasil identifikasi menggunakan wawancara dan pengamatan peneliti yang dapat dikategorikan sebagai individu yang resilien. Acuan yang digunakan untuk menjaring partisipan penelitian ini adalah reporter yang memiliki karakteristik resilien seperti dikemukakan Reivich dan Shatte (2002).

Partisipan dalam penelitian ini berjumlah 5 (lima) orang reporter yang terdiri atas 4 (empat) orang laki-laki dan 1 (satu) orang perempuan yang semuanya dari generasi milenial. Yaitu, JSM, SM, UW, MS, dan SA. Metode pengumpulan data yang digunakan adalah melalui wawancara, observasi dan dokumentasi. Wawancara dilakukan secara semi terstruktur dengan pedoman wawancara tertulis yang berisikan pertanyaan yang akan diajukan kepada partisipan (Peorwandari, 2005). Tujuan dari wawancara ini adalah untuk menggali informasi tentang sikap, perilaku dan aktivitas serta pandangan partisipan terkait dengan faktor pembentuk resiliensi. Rumusan pertanyaan wawancara disusun dari indikator-indikator yang diturunkan dari teori resiliensi. Setelah data terkumpul kemudian dianalisis dengan cara deskriptif analisis dengan metode kualitatif (Strauss, Gorbin, 2009). 


\section{HASIL DAN PEMBAHASAN}

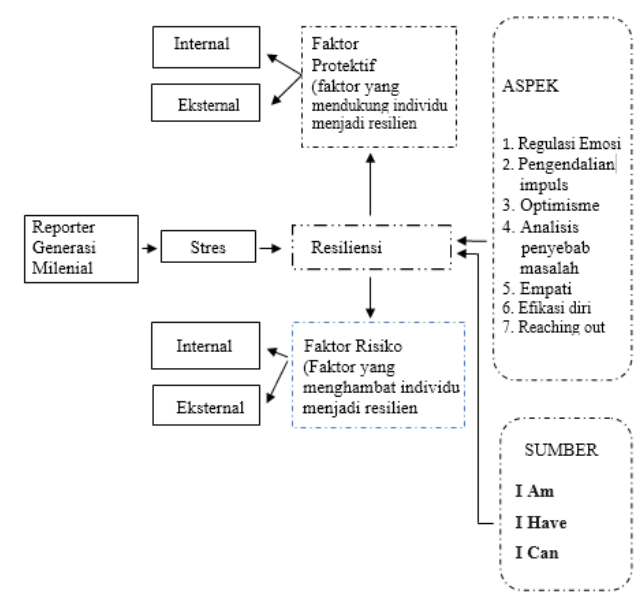

Faktor Internal Pembentuk Resiliensi Reporter Generasi Milenial di PT Jawa Pos Koran Surabaya

Menurut Reivich dan Shatte (2002), terdapat 7 (tujuh) faktor internal dalam diri individu yang memiliki karakter resilien seperti dalam gambar, yaitu regulasi emosi, pengendalian impuls, optimisme, analisis terhadap penyebab masalah, empati, efikasi diri, dan reaching out. Adapun analisis dan temuan faktor internal pembentuk resiliensi reporter generasi milenial di PT Jawa Pos Koran Surabaya adalah:

\section{Regulasi Emosi}

Regulasi emosi adalah kemampuan untuk selalu tenang dalam keadaan yang dipenuhi dengan tekanan (Reivich \& Shatté, 2002). Ekspresi emosi, berupa emosi negatif ataupun positif, yang dilakukan merupakan tindakan yang sehat dan konstruktif. Kemampuan regulasi yang baik dalam diri dapat mempermudah individu memecahkan berbagai masalah karena individu akan dapat mengendalikan perasaan negatif dalam dirinya.

Berdasarkan hasil penelitian yang dilakukan menunjukkan bahwa partisipan memiliki regulasi emosi yang berbeda-beda.
Secara sederhana kerangka konsep dalam penilitian ini adalah sebagai berikut:

Pada waktu individu sedang sedih, marah atau kecewa, ia memiliki cara mengekspresikan dengan cara yang berbedabeda. Sebanyak 2 (dua) reporter generasi milenial yang terdiri dari UW dan ELO mengekspresikan emosinya dengan lebih banyak menyimpannya atau jarang diungkapkan kepada orang lain. Namun, keduanya dapat mengontrol emosinya dengan baik. Sementara 3 (tiga) partisipan yang terdiri dari SM, JSM, dan SA mengungkapkan emosinya dengan sering menceritakan pengalamannya kepada orang lain, baik teman maupun anggota keluarganya. (Hasil wawancara dengan partisipan pada tanggal 10-20 Juni 2019).

Hal ini sesuai dengan pandangan Reivich \& Shatte bahwa seorang individu yang dapat mengekspresikan emosinya dengan tepat dan baik merupakan karakteristik dari individu yang resilien. Individu secara umum yang mampu untuk mengungkapkan emosinya dengan tepat dan tidak kontraproduktif maka dapat dikatakan termasuk individu yang resilien (Reivich \& Shatté, 2002).

2. Pengendalian Impuls

Pengendalian impuls adalah keterampilan individu untuk mengendalikan keinginan, dorongan, kegemaran, serta tekanan yang dimunculkan dari diri seseorang. Individu yang memiliki keterampilan mengendalikan impuls yang rendah, biasanya cenderung cepat mengalami perubahan emosi yang berdampak pada pengendalian psikologis maupun fisiologisnya. Individu kemudian memperlihatkan perilaku mudah emosi, kurang sabar, impulsif, dan berlaku agresif. Perilaku yang ditunjukkan ini akan menimbulkan orang di lingkungannya merasakan kurang nyaman sehingga 
berakibat pada hubungan sosial yang kurang harmonis antara individu dengan orang lain (Reivich dan Shatte, 2002).

$$
\text { Berdasarkan hasil penelitian }
$$
memperlihatkan bahwa 5 (lima) partisipan yang bekerja sebagai reporter generasi milenial di PT Jawa Pos Koran Surabaya mampu untuk mengendalikan impuls yang ada dalam dirinya. Para partisipan tidak menunjukkan adanya perilaku negatif seperti mudah emosi, kurang sabar, impulsif, dan perilaku agresif dalam menjalankan tugastugas pekerjaan sehari-harinya sebagai reporter. Dalam bergaul dengan lingkungan sekitarnya, baik atasan, rekan kerja, maupun narasumber, ia menunjukkan perilaku yang positif dan mampu mengenali apa yang harus dilakukan. Dengan demikian berarti mereka termasuk individu yang resilien karena memiliki salah satu karakteristik individu yang resilien, yaitu mampu mengendalikan impuls.

3. Optimisme

Meskipun bekerja dengan beban tinggi dan penuh tekanan serta berisiko, namun partisipan memiliki sifat optimistis dalam melaksanakan pekerjaannya. Sebanyak 5 (lima) partisipan yang menjalankan profesi sebagai reporter ini memiliki optimisme. Kenyataan di atas sesuai dengan pandangan Reivich dan Shatte (2002) yang menyatakan bahwa individu yang memiliki karakter resilien adalah individu yang optimistis. Ia meyakini bahwa segala sesuatu dapat berubah menjadi lebih baik. Individu memiliki keinginan dan harapan terhadap masa depannya, karirnya, dan percaya bahwa dirinya bisa menentukan arah kehidupannya dibandingkan orang yang pesimistis. Individu yang memiliki sikap optimistis fisiknya lebih sehat dibandingkan dengan yang pesimis, lebih produktif, dan kreatif dalam bekerja. (Reivich dan Shatte, 2002).

\section{Analisis Penyebab Masalah}

Ciri lain dari resiliensi pada individu adalah dapat mengetahui dan menganalisis penyebab masalah. Grotberg mengemukakan terdapat tiga sumber resiliensi salah satunya yaitu I Can. I Can adalah sumber resiliensi yang muncul dari kemampuan interpersonal dan sosial individu. Salah satu keterampilan tersebut adalah individu memiliki kemampuan untuk menilai suatu permasalahan, menganalisis penyebab munculnya masalah, serta mengetahui solusinya. Di samping itu, ia juga mempunyai sikap keteguhan diri untuk bertahan (survive) dengan suatu masalah sampai akhirnya masalah tersebut dapat diselesaikan (Desmita, 2010).

Berdasarkan hasil penelitian terhadap 5 (lima) partisipan dari generasi milenial yang menjadi reporter di PT Jawa Pos Koran Surabaya, mereka memiliki kemampuan unuk menganalisis penyebab masalah yang menjadi sumber tekanan dan kesulitan atau stresor yang sering mereka hadapi di lapangan. Di antara sumber stres itu antara dari faktor organisasional, faktor individual, maupun faktor ekonomi. Hasil dari analisa itu menjadikan mereka bisa keluar dari tekanan dan menjadi lebih tangguh.

\section{Empati}

Menurut Grotberg, karakteristik resilien itu bersumber dari dalam diri sendiri, misalnya perasaan mencintai, empati dan altruisme, di mana individu mencintai orang lain dan mengekspresikannya dengan berbagai cara. Individu tersebut biasanya menyatakan kepeduliannya terhadap orang lain berupa tindakan dan ucapan. Hal ini sebagaimana yang telah dilakukan oleh partisipan yang bekerja sebagai reporter di PT Jawa Pos Koran di Surabaya. Ketika ada teman kerjanya yang sedang mengalami kesulitan seperti beban kerja yang tinggi, misalnya, mereka saling berkomunikasi dan 
saling berupaya membantu berbagi tugas. Tidak hanya terkait kesulitan di lingkup pekerjaan, partisipan juga memiliki kepedulian dengan saling menjadi tempat berbagi atau mengungkapkan perasaannya dan berupaya membantu untuk menemukan solusinya.

\section{Efikasi Diri}

Efikasi diri merupakan gambaran sikap resilien di mana individu mencerminkan keyakinan bahwa ia dapat menyelesaikan masalah yang dialaminya dan yakin terhadap kemampuannya untuk mencapai kesuksesan. Dari hasil wawancara memperlihatkan bahwa partisipan memiliki sikap efikasi diri. Hal tersebut dapat dibuktikan dengan masing-masing memiliki cara tersendiri dengan kemampuan yang dimiliki untuk menyelesaikan masalah yang alami. Cara yang dilakukan antarpartisipan berbedabeda. Ada yang menyelesaikan masalah dengan kemauan belajar yang tinggi, bertanya dan berkomunikasi dengan atasan, hingga memanfaatkan sumber teknologi informasi.

Perilaku tersebut sejalan dengan pernyataan Grotberg bahwa karakteristik individu resilien adalah berupa kemampuan mengetahui bahwa dirinya merupakan orang yang bermanfaat, penting dan merasa bangga terhadap dirinya. Ketika mempunyai suatu masalah dalam hidupnya, individu tersebut akan terus bertahan dan mengatasi masalah tersebut dengan kepercayaan diri dan harga diri yang dimiliki (Schoon, 2006).

\section{Reaching out}

Reaching out adalah kemampuan seseorang untuk meningkatkan faktor-faktor yang positif dalam kehidupannya yang meliputi pula keberanian seseorang untuk memecahkan segala tekanan yang menghadang dalam kehidupannya. Individu yang memiliki sikap resilien dapat melakukan tiga hal dengan baik, yaitu dapat menganalisis risiko dari suatu masalah, memahami dirinya dengan baik, dan dapat menemukan makna serta tujuan hidup (Reivich dan Shatte, 2002).

Berdasarkan hasil penelitian yang dilakukan, partisipan memiliki reaching out. Mereka sudah memiliki tujuan dalam hidup dan dapat mengambil pelajaran dari setiap tekanan yang selama ini telah dirasakannya. Partisipan yang bekerja sebagai reporter di PT Jawa Pos Koran di Surabaya itu menjadikan masalah-masalah atau tekanan sebagai pelajaran, kemudian menjadikannya sebagai motivasi untuk menjadi lebih baik dalam menjalan tugas-tugas pekerjannya.

\section{Faktor Eksternal Pembentuk Resiliensi Reporter Generasi Milenial di PT Jawa Pos Koran Surabaya}

Berdasarkan yang data yang didapat penulis, banyak generasi milenial yang semula menjalani pekerjaan sebagai reporter tidak berhasil dan akhirnya memilih mengundurkan diri (turnover). Hal itu juga dialami reporter di PT Jawa Pos Koran di Surabaya. Akan tetapi, berbeda dengan lima partisipan dalam penelitian ini. Mereka dapat mengoptimalkan kemampuannya dan bangkit dari keterpurukan karena didorong oleh sejumlah faktor eksternal pembentuk relisiensi sebagai berikut:

\section{1 .Keluarga}

Keluarga merupakan unsur pertama dan utama dalam membentuk karakter resilien. Keluarga adalah tempat untuk bisa mengembangkan diri, menanamkan nilainilai luhur serta sebagai tempat berlindung. Dari hasil penelitian yang dilakukan terhadap 5 (lima) partsipan yang menjadi reporter di PT Jawa Pos Koran Surabaya dari generasi milenial ini juga mendapatkan dukungan dari anggota keluarganya. Baik orang tuanya maupun istrinya. Dukungan antara lain dengan memberikan motivasi untuk tidak mudah berputus asa, memiliki 
semangat tinggi, mempunyai kemauan kuat, kejujuran, hingga mendoakannya.

Menurut Grotberg, kekuatan itu terbentuk dalam diri atau disebut (I Have), yang merupakan dukungan dan sumber eksternal untuk meningkatkan resiliensi. Faktor tersebut merupakan karakteristik resiliensi yang bersumber dari pemaknaan individu terhadap besarnya dukungan dan sumber daya yang diberikan oleh lingkungan sosial (Desmita, 2010). Sebelum menyadari siapa dirinya $(\mathrm{I} \mathrm{Am})$ atau apa yang dapat dilakukan (I Can), individu membutuhkan dukungan eksternal dan sumberdaya dari anggota keluarga untuk terus berupaya mengembangkan dirinya dalam meletakkan fondasi, yang menjadi inti untuk mengembangkan resiliensi.

\section{Pergaulan}

Pergaulan merupakan interaksi yang dilakukan oleh parisipan dengan lingkungan sosial. Baik di lingkungan kerja maupun di masyarakat. Pergaulan sangat mempengaruhi terhadap proses resiliensi. Jika pergaulan dilakukan dengan orang yang memiliki motivasi yang tinggi, maka individu akan cenderung mengikutinya. Demikian juga apabila bergaul dengan orang yang memiliki semangat kerja tinggi, kreatifitas tinggi, perilaku yang baik serta optimis, maka individu akan terpengaruh dengan perilaku itu. Sebaliknya, apabila bergaul dengan orang yang memiliki motivasi rendah, perilaku kurang baik, mudah mengeluh dan pesimis, maka perilaku tersebut akan mempengaruhi individu bersangkutan.

Berdasarkan hasil penelitian di PT Jawa Pos Koran di Surabaya, reporter dari generasi milenial yang tetap bertahan juga karena melakukan pergaulan dengan lingkungan yang mendukung. Mereka aktif mengikuti kegiatan positif baik di lingkungan kerja maupun masyarakat. Hal ini selaras dengan pernyataan Grotberg bahwa teman sebaya akan bertindak dengan cara menunjukkan perilaku yang dapat diterima yang akan mempengaruhi orang lain. Mereka akan diberikan bantuan atau arahan oleh temannya jika mengalami kesulitan dalam beraktivitas. Oleh karena itu teman atau orang-orang yang ada di sekitar akan menjadi role models bagi individu tersebut (Reivich dan Shatte, 2002).

\section{Faktor Risiko}

Faktor risiko dapat terjadi karena kondisi budaya, ekonomi, atau medis yang memposisikan individu dalam risiko kegagalan pada waktu berhadapan dengan situasi yang sulit. Faktor risiko memperlihatkan bermacam-macam pengaruh yang dapat memperbesar kemungkinan timbulnya beberapa hal yang menyimpang dan dapat menimbulkan keadaan yang lebih serius lagi. Risiko adalah predisposisi individu yang meningkatkan kelemahan individu terhadap hasil negatif. Dampak lingkungan, yang dapat menimbulkan keadaan yang mendatangkan resiko. Rantai resiko akan muncul apabila ada hubungan antar berbagi variabel resiko (Maddi dan Khoshaba, 2005).

Berdasarkan hasil penelitian, meskipun bekerja sebagai reporter di PT Jawa Pos Surabaya seringkali mendapatkan tekanan dan risiko dalam bekerja, partisipan memiliki ketenangan jiwa dan kemauan belajar yang kuat, sehingga memotivasi dirinya untuk terus bertahan dalam melanjutkan karirnya sebagai reporter. Kesehatan badannya dipengaruhi oleh kondisi psikologisnya, apabila jiwa sehat karena tidak mudah larut dalam setiap tekanan yang dirasakannya maka badannya juga akan sehat.

\section{Faktor Protektif}

Faktor protektif merupakan ciri khas pada seseorang atau keadaan dari keluarga, 
lingkungan sekolah, ataupun kelompok yang meningkatkan kemampuan seseorang ketika akan menghadapi tantangan dengan baik (Reivich dan Shatte, 2002). Suatu hubungan antara proses sosial dan intrapsikis dapat menimbulkan seseorang untuk bisa menanggulangi kesulitan dan semua bentuk tantangan dalam kehidupan secara baik. Dyer dan McGuinness menjelaskan bahwa resiliensi sebagai proses yang secara terus menerus. Salah satu faktor yang dominan dipengaruhi oleh faktor protektif, yang mana individu dapat menghadapi kesulitan dan bergairah dalam menjalani kehidupannya (Reivich dan Shatte, 2002) dan (Ahern, 2007).

Dari hasil penelitian yang dilakukan, kelima partisipan yang menjadi reporter di PT Jawa Pos Koran, memiliki hubungan yang baik dengan keluarga, teman, dan lingkungan sosial lainnya. Interaksi yang baik ini menjadi modal sehingga dapat menanggulangi tekanan dan kesulitan yang dihadapi. Hubungan yang baik itu akan membuat partisipan mendapatkan bimbingan dan arahan sehingga memiliki motivasi yang kuat dan tidak mudah depresi. Ia tidak malu dan menarik diri dari lingkungan sosialnya, akan tetapi aktif dalam beragam kegiatan. Hal ini dilakukan karena pengaruh penanaman nilai-nilai yang diajarkan keluarga dan saat mengenyam pendidikan. Oleh karena itu, partisipan memiliki resiliensi dalam bentuk sikap protektif, di mana mereka dapat menghadapi kesulitan dan tetap bergairah dalam menjalani kehidupannya.

\section{KESIMPULAN DAN SARAN}

Berdasarkan pembahasan dapat disimpulkan bahwa partisipan dari generasi milenial yang bekerja sebagai reporter di PT Jawa Pos Koran Surabaya memiliki faktor pembentuk resiliensi yang berbeda-beda.
Resiliensi yang dimaksudkan adalah kemampuan untuk bangkit dari tekanann dan kesulitan selama menjalankan pekerjaan sebagai reproter yang termasuk profesi dengan tingkat stres tinggi.

Dari hasil penelitian, faktor internal pembentuk resiliensi yang terjadi pada reporter generasi milenail di PT Jawa Pos Koran Surabaya adalah sebagai berikut: Berkaitan dengan regulasi emosi, mereka mengekspresikan dengan cara-cara yang berbeda, ada yang mengekspresikannya dengan cara lebih sering diam dan ada yang mengungkapkan emosinya dengan curhat kepada orang lain. Selanjutnya dalam pengendalian impuls, mereka dapat mengendalikan hasrat dan keinginannya sehingga melakukan tindakan yang terbaik berdasarkan kemauannya sendiri, akan tetapi dipikirkan terlebih dahulu. Apakah tindakan tersebut berdampak negatif atau merugikan orang lain. Dalam optimisme, partisipan memiliki sifat optimis dan pantang menyerah. Mereka bekerja dengan keras dan memiliki kemauan belajar kuat untuk meraih harapan dan keinginannya. Demikian halnya dalam analisis penyebab masalah, ia memiliki kemampuan unuk mengetahui dan menganalisis penyebab masalah yang dihadapi dan menyadarinya. Selain itu, ia memiliki empati terhadap masalah orang lain dan lingkungannya. Dalam efikasi diri, masing-masing individu memiliki cara tersendiri dalam menyelesaikan masalah. Pada diri partisipan juga memiliki semangat untuk dapat bangkit kembali (reaching out) setelah mengalami permasalahn dan mampu mengambil hikmahnya, kemudian dijadikan sebagai motivasi untuk menjadi lebih baik dalam kehidupan. Adapun faktor eksternal pembentuk resiliensi pada reporter generasi milenial di PT Jawa Pos Koran di Surabaya banyak dipengaruhi oleh faktor dukungan keluarga dan faktor pergaulan. 
Saran diberikan agar reporter generasi milenial di PT Jawa Pos Koran di Surabaya tetap antusias dan memiliki motivasi tinggi dalam melaksanakan pekerjaannya di tengah tingkat kompetisi yang semakin ketat, maka dibutuhkan dukungan dari lingkungan sosialnya. Terutama dari keluarga maupun lingkungan kerjanya. Dengan demikian, mereka mampu bertahan dalam keadaan apapun dalam mewujudkan cita-citanya di tengah menjalankan pekerjaan sebagai reporter dengan tingkat stresor yang tinggi. Hal itu juga berdampak positif terhadap keberlangsungan perusahaan.

\section{REFERENSI}

Ahern, N. (2007). Resiliency in adolescent college students. College of Health and Public Affairs.

Cardoso, G., 2006, The Media in The Network So-ciety: Browsing, News, Filters, and Citizenship, Lu-lu.com.

Desmita, 2010. Psikologi Perkembangan, PT

Remaja Rosdakarya, Jakarta.

Djuroto, Totok,. 2004. Manajemen

Penerbitan Pers, Bandung : Remaja Rosdakarya.

Dyer, J. G. and McGuinness, T. M., 1996. Resilience: Analysis of the concept, Archives of Psychiatric Nursing, 10, 276-282.

Grotberg, E.H., 1999. Inner strength : How to Find the Resilience to Deal with anything. California. New Harbinger Publications.

Grotberg, E.H., 1995. A Guide to Promoting Resilience in Children: Strengthening the Human Spirit. Den Haag: Bernard van Leer Foundation.
Hannus, Sonja. 2016. Traits of the Millennial Generation: Motivation and Leadership.

Lancaster, L. C. and Stillman, D., 2002. When Generations Collide. Who They Are. Why They Clash. How to Solve the Generational Puzzle at Work. New York: Collins Business.

Lazarus, R.S \& Folkman, S. 1984. Stress appraisal and coping. Newyork : Springer Publishing Company.Inc.

Maddi, S. R., \& Khoshaba, D. M. (2005). Resilience at Work: How to Succeed no Matter what Life Throws at You. New York: Amacom Books.

Meyer, P., 2009. The Vanishing Newspaper: Saving Journalism in the Information Age, University of Missouri Press, Columbia.

Molkan, D., 2007. Profesi Jurnalistik dan Garis Kematian, Artikel, Fakultas Ilmu Komunikasi, Unpad, Bandung.

Pratopo, W.M., \& Kusajibrata, N., 2017. Komodifikasi Wartawan di Era Konvergensi: Studi Kasus Tempo, Jurnal Komunikasi Indonesia, Departemen Ilmu komunikasi Fisip, Universitas Indonesia.

Poerwandari, E. K., 2005. Pendekatan kualitatif untuk penelitian perilaku manusia (edisi.Ketiga), LPSP3 Fakultas Psikologi Universitas Indonesia.

Reivich, K., \& Shatte, A. 2002. The resilience factor: 7 essential skill for overcoming life's inevitable obstacles. New York: Broadway Books.

Schoon, I. 2006. Risk and Resilience: Adaptation in Changing Times. New York: Cambridge University Press. 